\title{
PECULIARITIES OF THE COMMUNICATIVE METHOD USE OF TEACHING FOREIGN LANGUAGES AT NON-LINGUISTIC HIGHER EDUCATIONAL ESTABLISHMENTS
}

\section{ОСОБЛИВОСТІ ВИКОРИСТАННЯ КОМУНІКАТИВНОГО МЕТОДУ ВИКЛАДАННЯ ІНОЗЕМНИХ МОВ У НЕЛІНГВІСТИЧНИХ ВИЩИХ НАВЧАЛЬНИХ ЗАКЛАДАХ}

UDC 378.147:811.111

DOI https://doi.org/10.32843/2663-

$6085 / 2020 / 24-2.9$

Kormiltsyna S.Yu., Lecturer of the Department of Foreign Languages of Professional Orientation Chernihiv National University of Technology

Hrechok L.M., Senior Lecturer of the Department of Foreign Languages of Professional Orientation Chernihiv National University of Technology
The article deals with the communicative method as an active type of teaching foreign languages to students at non-linguistic higher educational establishments. The main objective of teaching foreign languages is to form the communicative competence of future professionals who are able to communicate in a foreign language. The authors identify the peculiarities of the communicative method use of teaching foreign language, its features and basic principles of learning applied within it. The concept under consideration is the importance of speech activity in a foreign language. The issue of learning a foreign language using a communicative method is becoming relevant nowadays. Therefore, it is necessary to form a tendency to strengthen the communicative orientation of the educational process. Communicative competence is to be of primary importance for the methodological content of a foreign language class. The analysis of many works has been made to show the problem of activating the process of learning a foreign language by means of communicative method. The main features of the communicative method have been given. It has been proved that the communicative method is the most progressive and effective method of learning a foreign language. This method clearly shows the great importance of speech skills, and offers exercises for their consistent formation. All this in turn gives grounds to assert that the communicative method of teaching is of paramount importance in foreign language learning. The conclusion has been made that the essence of the communicative method of teaching foreign languages at non-linguistic universities is to develop the student's personality, prepare them for intercultural communication and develop their selfeducational potential to meet personal interests in learning a foreign language.

Key words: communicative method, learning, speech, new techniques, competence, communicative competence, language competence, social competence.

у статті розглядається комунікативний метод як активний тип навчання іноземних мов студентів у нелінгвістичних вищих навчальних закладах. Основна мета навчання іноземних мов - ссрормувати комунікативну компетентність майбутніх фрахівців, які вміють спілкуватися іноземною мовою. Автори визначають особливості використання комунікативного методу навчання іноземної мови, його особливості та основні принципи навчання, що застосовуються в ньому. Розглянуто концепцію важливості мовленнєвої діяльності іноземною мовою. Питання вивчення іноземної мови за допомогою комунікативного методу стає актуальним нині. Тому необхідно фрормувати тенденцію до посилення комунікативної спрямованості навчального процесу. Комунікативна компетентність має мати першочергове значення для методичного змісту класу іноземної мови. Проведено аналіз багатьох наукових праць, щоб показати проблему активізації процесу навчання іноземної мови завдяки комунікативному методу. Наведено основні особливості комунікативного методу. Доведено, що комунікативний метод $\epsilon$ найбільш прогресивним та ефрективним методом вивчення іноземної мови. Цей метод наочно показує велике значення мовленнєвих навичок і пропонує вправи для їх послідовного формування. Все че, у свою чергу, дає підстави стверджувати, що комунікативний метод навчання має першорядне значення в навчанні іноземної мови. Зроблено висновок, що суть комунікативного методу викладання іноземних мов у нелінгвістичних закладах вищої освіти полягає у формуванні особистості студента, підготовці його до міжкультурного спілкування та розвитку його самоосвітнього потенціалу для задоволення особистих інтересів у вивченні іноземної мови.

Ключові слова: комунікативний метод, навчання, мовлення, нові прийоми, компетентність, комунікативна компетентність, мовна компетентність, соціальна компетентність.
Problem statement in general. Nowadays, a foreign language is not just a part of a nation's culture, but it is also the key to the of students' future careers' success. With the growing demand for specialists with knowledge of a foreign language, the requirements for the efficiency and quality of their training are growing. The search for new teaching methods, their improvement, development and implementation of new techniques in the educational process is intensive. Achieving a high level of language proficiency is impossible without fundamental language training in higher education. The main objective of teaching foreign languages is to form the communicative competence of future professionals who are able to communicate in a foreign language within the communication topics and situations proposed by the curriculum. It should be noted that the new curriculum is based on the recommendations of the Council of Europe, which focus on the formation of socio-cultural competence and the need to teach intercultural communication, which within the socio-cultural approach to foreign language learning is defined as functionally 
conditioned communicative interaction of people with different cultural values, their independent awareness to different subcultures.

In this regard, the issue of learning a foreign language using a communicative method is becoming relevant.

Therefore, it is necessary to form a tendency to strengthen the communicative orientation of the educational process, its closeness to the real communicative process. In our opinion, communicative competence is to be of primary importance for the methodological content of a foreign language class.

Current research analysis. In the methodological literature, the issue of teaching communicative competence has been repeatedly raised. The communicative method was initiated by the works of E.P. Shubin. The ideas of the communicative method of teaching were developed by other authors (H.V. Rogova, Y.I. Passov, V.L. Skalkin, L.P. Malyshevska, A.P. Starkov). This method was developed on the basis of the ideas of linguists, psychologists and methodologists (V.A. Artemov, I.M. Berman, V.A. Buchbinder, O.O. Leontiev, M.V. Lyakhovytsky and others). The communicative method is actively studied in foreign methodology by $\mathrm{K}$. Black, E.Y. Joyner, H. Besse. Analysis of these works shows that the problem of activating the process of learning a foreign language by means of the communicative method has received considerable attention.

The objective of the article is to identify the peculiarities of the communicative method use of teaching foreign languages at non-linguistic higher educational establishments.

Presenting the main material. The communicative method is based on the idea that a language is used for communication and, therefore, the purpose of language learning should be of communicative competence, which includes language competence (mastering language material and its employment in speech patterns), sociolinguistic communication (ability to use language units in accordance with communication situations), competence discourse (the ability to understand and achieve coherence in the perception and generation of individual utterances within the meaningful communicative-language clusters), so-called "strategic competence" (degree of acquaintance with the socio cultural context of language functioning) social competence (ability and readiness to communicate with others). The emergence of the communicative method and the very term "communicative competence" was influenced by the concept of language competence of N. Khomsky, which means the ability of the speaker to generate grammatically correct structures.

The main features of the communicative method: 1) task - to teach students to speak a foreign language, if not at the level of the native speaker, then at least at the level necessary for further work; 2) teach- ing aids - business games that simulate real communication situations, most typical for this group of students. Mastering the means of communication (phonetic, lexical, grammatical), as well as types of speech activity (speaking, listening, reading and writing) occurs during the practical application of these means and types of speech activity in the process of communication; 3) limited use of native speech while learning a foreign language. In fact, instead of translating lexical units from a foreign language into the native language, the lecturer at the initial stages uses visual aids (drawings, photographs, etc.) and at subsequent stages - the explanation of foreign words in a foreign language; 4) the study of grammar is mostly intuitive, i. e, in contrast to traditional methods, where grammar and vocabulary are the main subjects of learning, when learning the communicative method, grammar is needed only for correct sentence construction, but students are required not to memorize grammatical rules mechanically, but with intuitive feeling of correctly built speech patterns; 5) contextual learning of lexical material, i. e not isolated units as in the traditional methodology goes, but only in the context during its application.

Communicative method of teaching foreign languages is today the most popular in the world. And even those who have a bad idea of what this method is, firmly believe that it is the most progressive and effective method of learning a foreign language [3, p. 67].

J.M. Kolker dwells in detail on the following point: "In recent decades, traditional foreign language teaching is opposed to communicative and intensive methods" [1, p. 48].

Communicative learning of foreign languages is an activity, because language communication is carried out through "language activities", which, in its turn, serves to solve the problems of productive human activity in terms of social human communication (V.A. Zimova, R.A. Kitaygorodskaya, A.A. Leontiev). The participants of the communication try to solve real and imaginary problems of joint activity with the help of a foreign language.

The activity type learning peculiarity is associated primarily with a particular type of speech activity, so we find its application while reading, listening, translating, etc. And only the common method displays the features of activity type of learning as a whole.

According to O.V. Passov, the author of the communicative method, communicativeness presupposes the speech orientation of the educational process, which is not so much that the speech practical goal is pursued (in fact, all areas of the past and present set such a goal), but practical language application. Practical speech orientation is not only the goal, but also the means, where both are dialectically interconditioned.

In fact, at all stages of learning the process is communicative. But there are a number of points that require special training. Thus, for the ability to 
communicate a special role is played by: the ability to enter into communication, to stop it and start; the ability to pursue their strategic line in communication, to implement it in tactics of behavior contrary to the strategies of those who communicate; the ability to select new (several) language partners each time, change the roles of partners, or the direction of communication, the ability to probabilistically predict the behavior of language partners, their statements, the issue of a situation.

The modern communicative method is a harmonious combination of many ways of learning foreign languages, being probably at the top of the evolutionary pyramid of different educational methods.

At the present stage of learning foreign languages, most linguists consider "communicative" to be the most effective and criticize traditional methods that work on the principle of "from grammar to vocabulary, and then the transition to consolidation exercises". Artificially created exercises do not shape the user of the language, and a person who learns the language by this method will be silent rather than say the wrong phrase. And "communicativeness", on the contrary, is bound "to break the ice".

The Communicative Approach develops all language skills, from speaking to reading and listening. Grammar is mastered in the process of communication in the language: a student first memorizes words, expressions, language patterns and only then begins to understand what they are in the grammatical sense. The goal is to teach a student to speak a foreign language not only fluently but also correctly.

Rules, meanings of new words are explained by the teacher with the help of familiar vocabulary, grammatical constructions and expressions, with gestures and facial expressions, drawings and other visual aids. Computers with CDs, the Internet, TV programs, newspapers, magazines, etc. can also be of help. All this facilitates students' interest to history, culture, country traditions in the process of learning.

At foreign language classes, the teacher creates situations in which students communicate in pairs with each other, in groups. This makes the lesson more diverse. Working in a group, students show language independence. They can help each other; successfully correct the statements of their partners.

The teacher in the class assumes the functions of the organizer of communication, asks questions, and pays attention to the original opinions of the participants, acts as an arbiter in the discussion of controversial issues.

Unlike audio-lingual and other methods based on repetition and memorization, the communicative method sets the exercises "with an open ending": students themselves do not know what will turn into their activities in the classroom, everything will depend on the reactions and answers. Every day new situations are employed. This keeps the students' inter- est going: after all, everyone wants to communicate on the topic.

Speaking takes up most of the class time (though reading and writing are of great importance too).

It is necessary to name also the basic principles of learning which are applied within the communicative method in a foreign language [2, p. 57]. They include:

1) The principle of speech orientation or the principle of communicativeness. It consists not so much in the pursuit of a speech practical goal, but in the fact that the path to this goal is the practical use of the language itself.

2) The principle of individualization. It is always necessary to take into account the individual - psychological characteristics of students, their abilities to carry out speech and educational activities, and mainly their personal properties.

3) The principle of authenticity. This principle means that the most important characteristic of the communicative approach is the use of authentic materials, such as those used by native speakers.

4) The principle of interactivity. According to this principle, learning takes place mainly in groups, because group interaction creates mutual information fund to research a subject, which they use together.

5) The principle of intensive use of students' background knowledge. This principle is extremely relevant at non-language higher education institutions. After all, the main task is to teach students to work with texts in their specialty, to understand professional terminology. According to the communicative method, students must be able not only to read and translate texts in a professional field, but also to talk on these topics.

6) The principle of situationality or contextual conditionality. It means that language and language techniques are used within the relevant social context, i. e situationally. It is namely context allows to recognize, semantize and memorize the meaning of each new lexical unit [2, p. 97].

Regarding to the mentioned above communicative method of teaching a foreign language allows us to state that the subject of study in this case is speech activity in a foreign language. This method clearly shows the great importance of speech skills, and offers exercises for their consistent formation. All this in turn gives grounds to assert that the communicative method of teaching is of paramount importance in foreign language learning.

Conclusions. Thus, the essence of the communicative method of teaching foreign languages at non-linguistic universities is to develop the student's personality, prepare them for intercultural communication and develop their self-educational potential to meet personal interests in learning a foreign language.

The prospect of further research of this problem is open for consideration with other methods used to increase the students' knowledge in the process of learning a foreign language. 


\section{REFERENCES:}

1. Колкеря.М.,УстиноваЕ.С.,ЕналиеваТ.М.Практическая методика обучения иностранному языку: учебное пособие. Москва : Академия, 2000. 264 с.

2. Пассов Е.И. Коммуникативный метод обучения иноязычному говорению. Москва : Просвещение, 1991. 223c.
3. Пассов Е.И. Коммуникативный метод обучения иноязычному говорению. Москва, 1985. 208 c.

4. Threshold 1990. Pergamon Institute of English (Oxford): materials for language and practice Threshold Series. J.A. van Ek, J.L.M. Trim, Council of Europe. Cambridge University Press. 1988. 184 p. 